УДК 616-089.891:612.176

DOI 10.11603/2414-4533.2020.4.11778

ОМ. М. ГАЛЕЙำ, А. А. ГУДИМА², І. Я. ДЗЮБАНОВСЬКИЙ², О. І. ДЗЮБАНОВСЬКИЙ²

Волинська обласна лікарня ${ }^{1}$

Тернопільський національний медичний університет імені І. Я. Горбачевського МОЗ України²

\title{
Аналіз періопераційного стресу в паціентів після симультанних лапароскопічних операцій
}

\begin{abstract}
Мета роботи: на основі варіативності сецевого ритму оцінити ступінь періопераційного стресу в пацієнтів з лапароскопічним лікуванням грижі стравохідного отвору діафрагми та симультанними операціями.

Матеріали і методи. Проведено обстеження 332 пацієнтів, які лікувалися з приводу грижі стравохідного отвору діафрагми (ГСОД) із 2015 до 2019 р. Усім хворим виконано лапароскопічну крурорафію з фундоплікацією за Тупе. Сформовано дві групи: першу групу - основну - склали пацієнти, які проходили симультанне лапароскопічне операційне лікування ГСОД і жовчнокам'яної хвороби (ЖКХ) - 126 осіб. Другу - контрольну групу - пацієнти, яким виконували тільки лапароскопічну крурорафію і фундоплікацію - 206 осіб. Для оцінки операційного стресу за день до операції та через 1, 2, 3, 6, 12 год та 1, 2 і 3 доби післяопераційного періоду здійснювали реєстрацію варіаційної пульсограми з використанням кардіокомплексу “CardioLab+” 3 подальшим визначенням основних статистичних характеристик за методикою Р. М. Баєвського. Оцінку вірогідності відмінностей між контрольною та основною групами проводили з використанням непараметричного критерію Манна-Уїтні.

Результати досліджень та їх обговорення. Моновтручання з приводу грижі стравохідного отвору діафрагми та симультанні втручання за умов розробленої техніки лапароскопічних операцій у післяопераційному періоді у всі терміни спостереження супроводжуються практично однаковими відхиленнями статистичних показників варіабельності сецевого ритму. Відсутність у динаміці післяопераційноого періоду статистично значущих відмінностей досліджуваних показників між групами хворих із моно- і симультанними втручаннями за рівнем симпатикотонії та ступенем централізації регуляції серцевого ритму свідчить про однаковий рівень післяопераційного стресу і вказує на безпечність і перспективність одномоментних симультанних операцій.
\end{abstract}

Ключові слова: грижа стравохіжного отвору діафрагми; лапароскопічна фундоплікація; операційний стрес.

Постановка проблеми і аналіз останніх досліджень та публікацій. Розвиток технологій лапароскопічних операційних втручань у пацієнтів з поєднаною хірургічною патологією черевної порожнини створює передумови одночасного проведення симультантних операцій. Останнє сприяє прискоренню одужання пацієнта та знижує його вартість. Основною пробемою симультантних операцій є їх додаткова травматичність та тривалість, що поглиблює операційний стрес і може сприяти збільшенню частоти післяопераційних ускладнень [1].

Все це ставить додаткові вимоги до оснащення операційних приміщень, зниження травматичності та інвазивності хірургічних утручань, адекватності передопераційної підготовки пацієнта, анестезіологічного супроводу та ведення хворих у післяопераційному періоді [2].

Подібна проблема має місце i в хірургії жовчнокам'яної хвороби (ЖКХ). Від неї страждає від 15 до 20 \% дорослого населення західних країн. Серед них до 12 \% хворих мають супутню грижу стравохідного отвору діафрагми (ГСОД). Це спонукало нас розробити техніку симультанної операції, спрямованої на операційне лікування ГСОД та ЖКХ, про що йшла мова у наших попе- редніх публікаціях. За цих умов одним з важливих критеріїв ефективності симультанних операцій порівняно $з$ моновтручаннями $є$ тяжкість операційного стресу [3].

В умовх стресу однією з перших відбувається адаптаційна перебудова серцево-судинної системи, що відображається на варіативності серцевого ритму $[4,5]$.

Однак оцінка операційного стресу за умов розроблених нами симультантних операцій з приводу ГСОД та ЖКХ порівняно з моновтручанням не проводилася.

Мета роботи: оцінити на основі варіативності сецевого ритму ступінь до- та післяопераційного стресу в пацієнтів з лапароскопічним лікуванням грижі стравохідного отвору діафрагми та симультанними операціями.

Матеріали і методи. На базі КП "Волинська обласна клінічна лікарня” у відділенні малоінвазивної хірургії відібрано пацієнтів, які лікувалися з приводу ГПОД з 2015 до 2019 р. Всім виконано лапароскопічну крурорафію з фундоплікацією за Тупе. Сформовано дві групи: першу - основну групу - склали пацієнти, які проходили симультанне лапароскопічне операційне лікування ГПОД і ЖКХ 
(126 осіб). Другу - контрольну групу - пацієнти, яким виконували тільки лапароскопічну крурорафію і фундоплікацію (206 осіб). У першій групі використовували техніку введення і розстановки портів, яку ми розробили, у другій групі використовували класичну схему “Baseball diamond”.

Відбір до груп здійснювали винятково за принципами хірургічної коморбідності. Всі пацієнти проходили планове хірургічне лікування. Середній перід перебування хворого в стаціонарі до операції становив 1 ліжко-день.

Для оцінки операційного стресу всім пацієнтам контрольної та основної груп за день до операції та через 1, 2, 3, 6, 12 год та 1, 2 і 3 доби післяопераційного періоду здійснювали реєстрацію варіаційної пульсограми з використанням кардіокомплексу “CardioLab+” виробництва ХАИ-МЕДИКА, м. Харків. Запис проводили у палаті пацієнта в лежачому положенні не раніше, ніж через 7-10 хв адаптації до такого положення. Реєстрували не менше 100 кардіоінтервалів із подальшим визначенням основних статистичних характеристик за методикою Р. М. Баєвського [6, 7].

За отриманими записами визначали частоту серцевих скорочень (ЧСС), варіаційний розмах $(\Delta \mathrm{X})$ - різницю між максимальною і мінімальною тривалістю кардіоінтервалів, амплітуду моди (АМо) - відсоток кардіоінтервалів, які найчастіше зустрічаються, а також їх тривалість - моду (Мо).

За одержаними даними розраховували індекс напруження регуляторних систем Р. М. Баєвського (IH), який відображає ступінь централізації управління серцевим ритмом:

$$
\mathrm{IH}=\mathrm{AMo} /(2 \times \mathrm{Mo} \times \Delta \mathrm{X})
$$

Оцінку вірогідності відмінностей між контрольною та основною групами проводили з використанням непараметричного критерію МаннаУїтні.

Результати досліджень та їх обговорення. В результаті проведених обстежень ми встановили, що величина ЧСС (табл. 1, рис. 1) до операції між контрольною та основною групами статистично вірогідно не відрізнялася.

У післяопераційному періоді порівняно з доопераційним періодом показник зростав, досягаючи максимуму через 2 год (відповідно на 26,8 i $24,6 \%, \mathrm{p}<0,05)$. В подальшому в обох групах порівняння показник знижувався й, починаючи з 12 год післяопераційного періоду, статистично вірогідно від величини показника до операції не відрізнявся $(\mathrm{p}>0,05)$. Привертає увагу факт, що величина ЧСС у всі терміни післяоперацінйого періоду між групою хворих із лапароскопічною холецистектомією та симультанними операціями істотно не відрізнялася (p>0,05).

Аналіз величини варіаційного розмаху $(\Delta \mathrm{X})$ (табл. 2, рис. 2) встановив, що до операції показник істотно не відрізнявся між контрольною та основною групами ( $>>0,05)$.

У післяопераційному періоді динаміка величини $\Delta \mathrm{X}$ в групах порівняння була хвилеподібна з першим періодом зниження через 2 год (відповідно на 19,2 і 21,9 \%, p<0,05) та через 2 доби (відповідно на 12,8 і 15,5 \%, p<0,05). Через 3 доби показ-

Таблиця 1. Величина ЧСС (уд·ХВ $\left.{ }^{-1}\right)$ пацієнтів контрольної та основної груп до операції та в динаміці післяопераційного періоду (Me (LQ;UQ)) - медіана (нижній і верхній квартилі))

\begin{tabular}{||l|c|c|c||}
\hline \hline \multicolumn{1}{|c|}{ Період обстеження } & Контрольна група & Група симультанних операцій & p \\
\hline День до операції & $71,0(66,0 ; 75,0)$ & $72,0(67,0 ; 75,0)$ & $>0,05$ \\
\hline Післяопераційний період & \multicolumn{3}{|c||}{} \\
\hline 1 год & $87,0(80,8 ; 91,9)$ & $82,8(77,1 ; 86,3)$ & $>0,05$ \\
\hline 2 год & $90,0(83,7 ; 95,1)$ & $89,7(83,5 ; 93,5)$ & $>0,05$ \\
\hline 6 год & $84,0(78,1 ; 88,7)$ & $84,6(79,1 ; 88,1)$ & $>0,05$ \\
\hline 12 год & $78,0(72,5 ; 82,4)$ & $73,4(68,3 ; 76,5)$ & $>0,05$ \\
\hline 1 доба & $74,0(68,8 ; 78,2)$ & $76,6(71,3 ; 79,8)$ & $>0,05$ \\
\hline 2 доби & $73,0(67,8 ; 77,1)$ & $74,6(69,4 ; 77,7)$ & $>0,05$ \\
\hline 3 доби & $70,0(65,1 ; 74,0)$ & $71,9(66,9 ; 74,9)$ & \\
\hline
\end{tabular}

Примітка. Тут і в інших таблицях: - вірогідність відмінностей показника контрольної групи та групи симультанних операцій. 


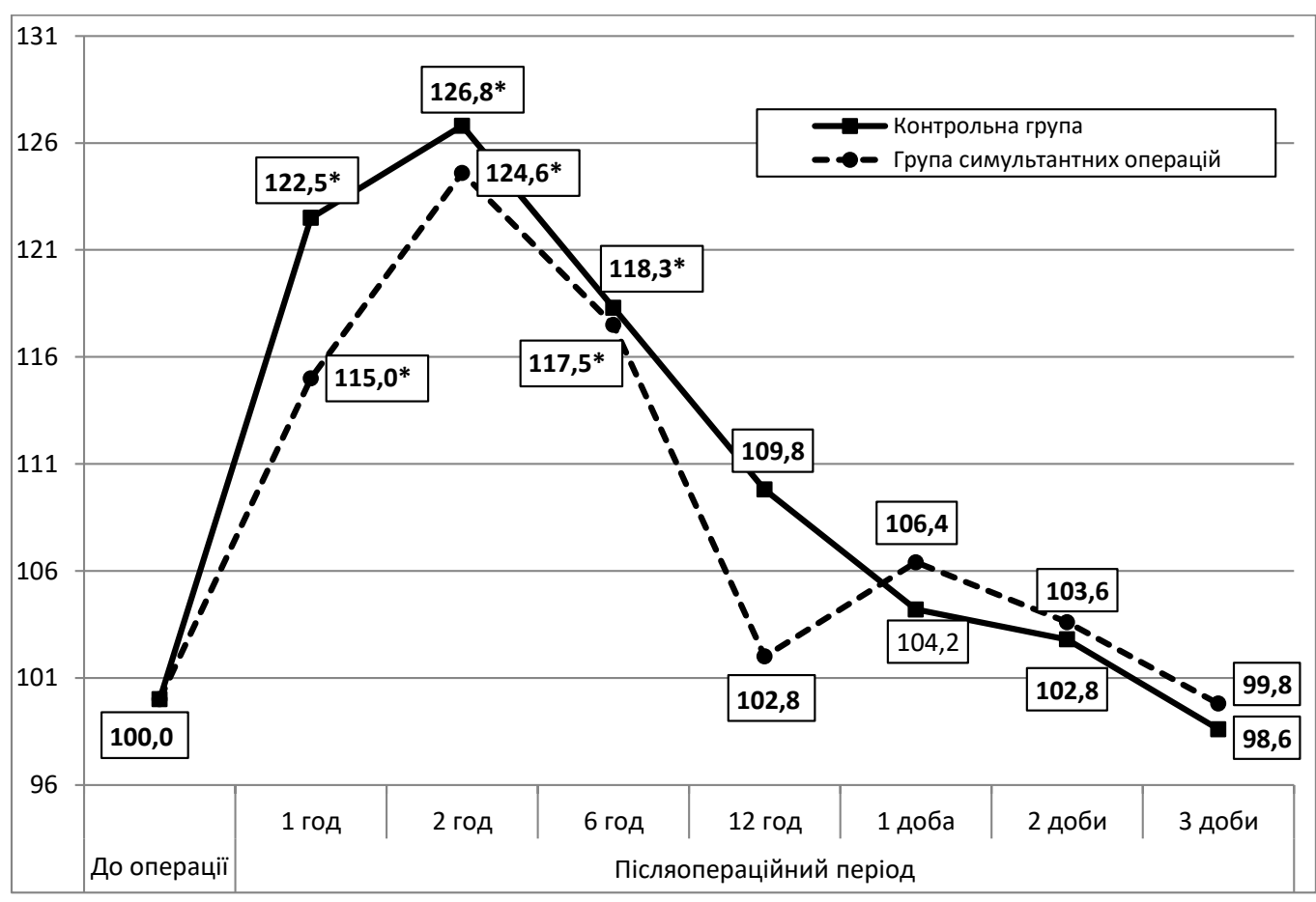

Рис. 1. Динаміка ЧСС (у відсотках до рівня контролю) пацієнтів контрольної та основної груп у післяопераційному періоді. (Примітка: тут і на інших рисунках: * - відмінності стосовно терміну до операції статистично вірогідні, $\mathrm{p}<0,05)$.

Таблиця 2. Величина $\Delta \mathrm{X}$ (c) пацієнтів контрольної та основної груп до операції та в динаміці післяопераційного періоду (Me (LQ;UQ)) - медіана (нижній і верхній квартилі))

\begin{tabular}{||l|c|c|c||}
\hline \multicolumn{1}{||}{ Період обстеження } & Контрольна група & Група симультанних операцій & $p$ \\
\hline День до операції & $0,156(0,148 ; 0,153)$ & $0,142(0,137 ; 0,153)$ & $>0,05$ \\
\hline Післяопераційний період & \multicolumn{2}{|c||}{} \\
\hline 1 год & $0,144(0,136 ; 0,156)$ & $0,130(0,125 ; 0,141)$ & $>0,05$ \\
\hline 2 год & $0,126(0,118 ; 0,138)$ & $0,112(0,107 ; 0,123)$ & $>0,05$ \\
\hline 6 год & $0,148(0,140 ; 0,160)$ & $0,134(0,130 ; 0,143)$ & $>0,05$ \\
\hline 12 год & $0,149(0,141 ; 0,161)$ & $0,133(0,124 ; 0,144)$ & $>0,05$ \\
\hline 1 доба & $0,151(0,143 ; 0,163)$ & $0,139(0,131 ; 0,146)$ & $>0,05$ \\
\hline 2 доби & $0,136(0,125 ; 0,140)$ & $0,121(0,125 ; 0,145)$ & $>0,05$ \\
\hline 3 доби & $0,176(0,168 ; 0,188)$ & $0,162(0,157 ; 0,173)$ & $>0,05$ \\
\hline
\end{tabular}

ник в обох групах зростав і в основній групі ставав істотно вищим, ніж до операції (на 14,1%, p<0,05).

Разом з тим у ході післяопераційного періоду істотних відмінностей між групами порівняння не спостерігали (p>0,05).

У свою чергу, динаміка величини Мо була подібною до величини ЧСС (табл. 3, рис. 3). До операції величина Мо між контрольною та основною групами істотно не відрізнлася ( $>0,05)$.

У динаміці величина Мо в обох групах до 2 год післяопераційного періоду порівняно з доопераційним рівнем знижувалася (відповідно на 21,1 i 19,7 \%, р<0,05). В подальшому показник зростав i, починаючи з 12 год післяопераційного періоду, статистично вірогдіно від доопераційного рівня не відрізнявся ( $>>0,05)$. 


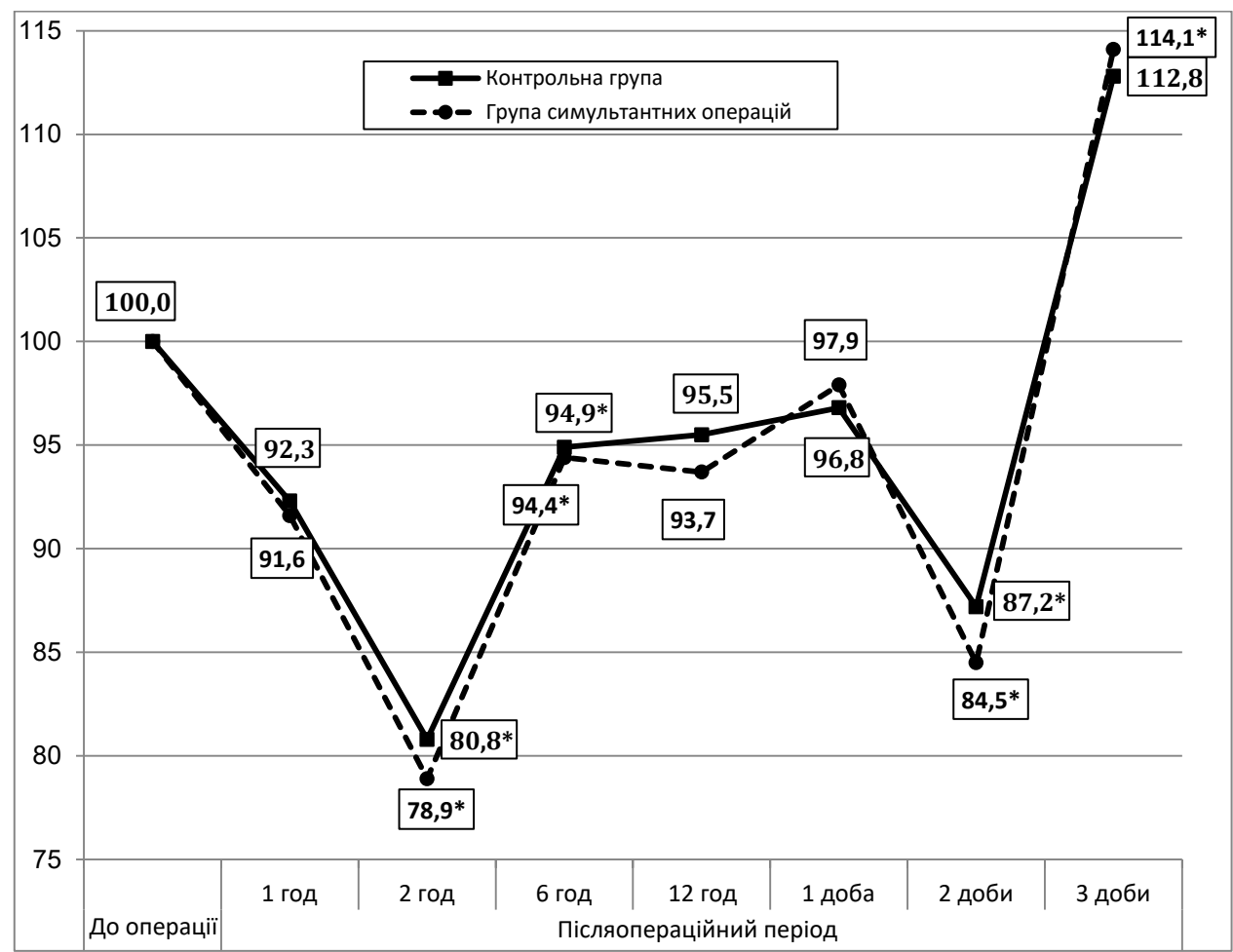

Рис. 2. Динаміка $\Delta \mathrm{X}$ (у відсотках до рівня контролю) пацієнтів контрольної та основної груп у післяопераційному періоді.

Таблиця 3. Величина Мо (c) пацієнтів контрольної та основної груп до операції та в динаміці післяопераційного періоду (Me (LQ;UQ)) - медіана (нижній і верхній квартилі))

\begin{tabular}{||l|c|c|c||}
\hline \multicolumn{1}{|c|}{ Період обстеження } & Контрольна група & Група симультанних операцій & $p$ \\
\hline День до операції & $0,865(0,800 ; 0,918)$ & $0,855(0,788 ; 0,918)$ & $>0,05$ \\
\hline Післяопераційний період & \multicolumn{2}{|c||}{} \\
\hline 1 год & $0,706(0,653 ; 0,750)$ & $0,743(0,686 ; 0,798)$ & $>0,05$ \\
\hline 2 год & $0,682(0,631 ; 0,724)$ & $0,686(0,633 ; 0,736)$ & $>0,05$ \\
\hline 6 год & $0,731(0,676 ; 0,776)$ & $0,726(0,669 ; 0,777)$ & $>0,05$ \\
\hline 12 год & $0,788(0,729 ; 0,836)$ & $0,838(0,773 ; 0,900)$ & $>0,05$ \\
\hline 1 доба & $0,830(0,768 ; 0,881)$ & $0,803(0,741 ; 0,862)$ & $>0,05$ \\
\hline 2 доби & $0,841(0,778 ; 0,893)$ & $0,825(0,761 ; 0,886)$ & $>0,05$ \\
\hline 3 доби & $0,877(0,811 ; 0,932)$ & $0,857(0,790 ; 0,919)$ & \\
\hline \hline
\end{tabular}

Порівняння контрольної та основної груп в післяопераційному періоді не виявило істотних відмінностей за величиною Мо (p>0,05).

Величина АМо (табл. 4, рис. 4) в доопераційному періоді між контрольною та дослідною групою теж не відрізнялася (p>0,05).

У динаміці післяопераційного періоду величина досліджуваного показника порівняно $з$ до- операційним рівнем зростала 3 максимумом через 2 год (відповідно на 21,9 і 20,9 \%, p<0,05). У подальшому показник знижувався й, починаючи 3 12 год післяопераційного періоду, в обох групах порівняння досягав рівня доопераційного періоду $(\mathrm{p}>0,05)$.

Порівняння величини АМо в післяопераційному періоді не виявило статистично значущих від- 


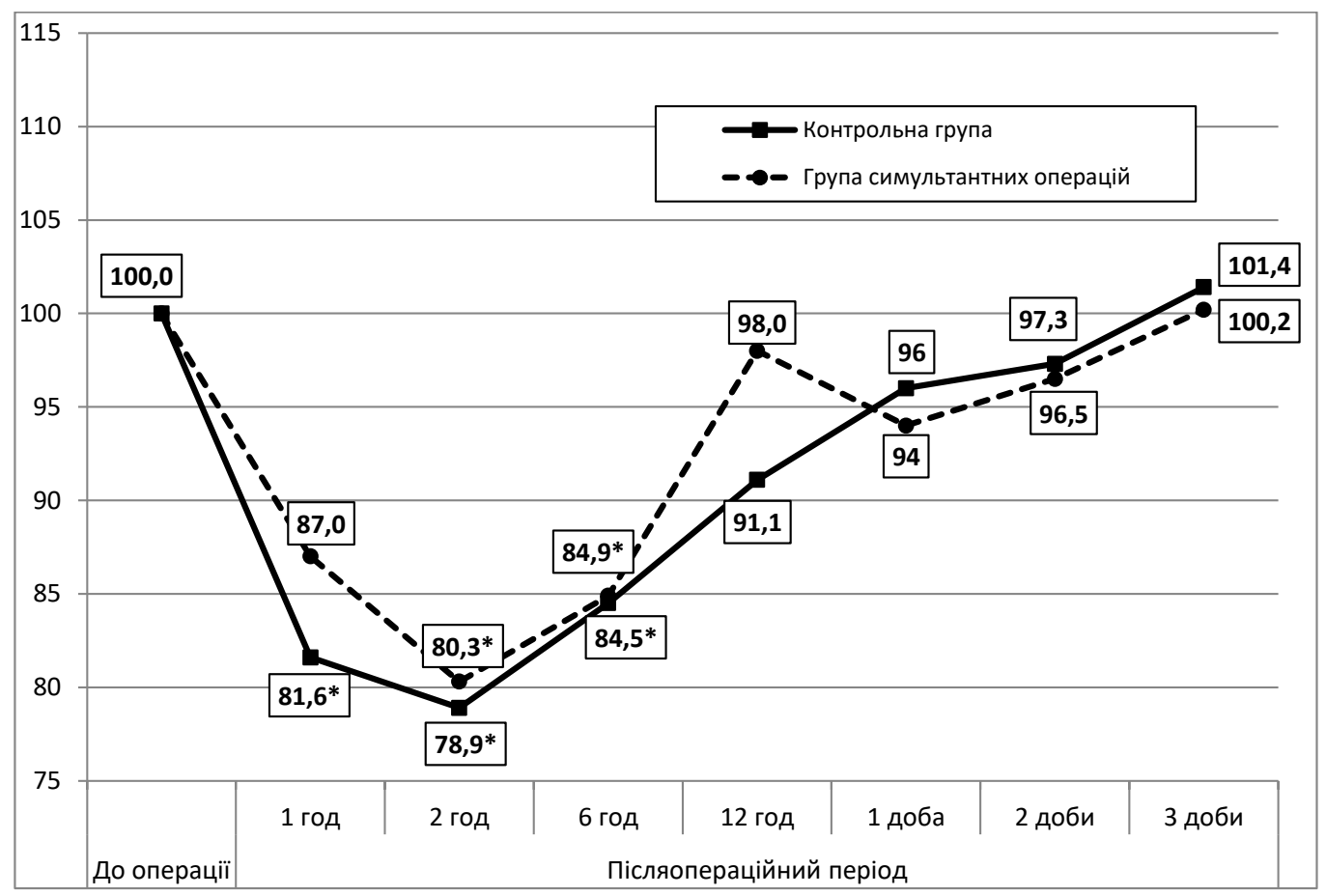

Рис. 3. Динаміка Мо (у відсотках до рівня контролю) пацієнтів контрольної та основної груп в післяопераційному періоді.

Таблиця 4. Величина АМо (\%) пацієнтів контрольної та основної груп до операції та в динаміці післяопераційного періоду (Me (LQ;UQ)) - медіана (нижній і верхній квартилі))

\begin{tabular}{||l|c|c|c||}
\hline \multicolumn{1}{|c|}{ Період обстеження } & Контрольна група & Група симультанних операцій & $p$ \\
\hline День до операції & $36,5(33,9 ; 38,5)$ & $38,3(35,6 ; 39,8)$ & $>0,05$ \\
\hline Післяопераційний період & \multicolumn{2}{|c||}{ (44,3 (41,6; 45,8) } & $>0,05$ \\
\hline 1 год & $42,5(39,9 ; 44,5)$ & $46,3(43,6 ; 48,1)$ & $>0,05$ \\
\hline 2 год & $44,5(41,9 ; 46,5)$ & $43,3(41,1 ; 45,3)$ & $>0,05$ \\
\hline 6 год & $41,5(38,9 ; 43,5)$ & $41,3(38,6 ; 42,8)$ & $>0,05$ \\
\hline 12 год & $39,5(36,9 ; 41,5)$ & $38,0(36,0 ; 40,3)$ & $>0,05$ \\
\hline 1 доба & $38,5(35,9 ; 40,5)$ & $38,8(36,0 ; 41,0)$ & $>0,05$ \\
\hline 2 доби & $36,5(33,9 ; 39,1)$ & $37,3(34,7 ; 40,3)$ & $>0,05$ \\
\hline 3 доби & $35,5(32,9 ; 38,5)$ & & \\
\hline
\end{tabular}

мінностей між контрольною та основною групами $(\mathrm{p}>0,05)$.

Інтегральним пазником напруження адаптаційних механізмів є величина IH.

Обстеження показали, що величина IH в доопераційному періоді (табл. 5, рис. 5) між контрольною та основною групами істотно не відрізнялася $(\mathrm{p}>0,05)$.
У динаміці показник до 2 год післяопераційного порівняно з доопераційним рівнем зростав: у контрольній групі - на 92,4 \%, в основній - на 92,5 \% (p<0,05). В подальшому показник знижувався й через 6 год в обох групах порівняння істотно не відрізнявся від доопераційного рівня ( $>>0,05)$. Через 2 доби спостерігали повторне збільшення величини IН в обох дослідних групах. Проте отрима- 


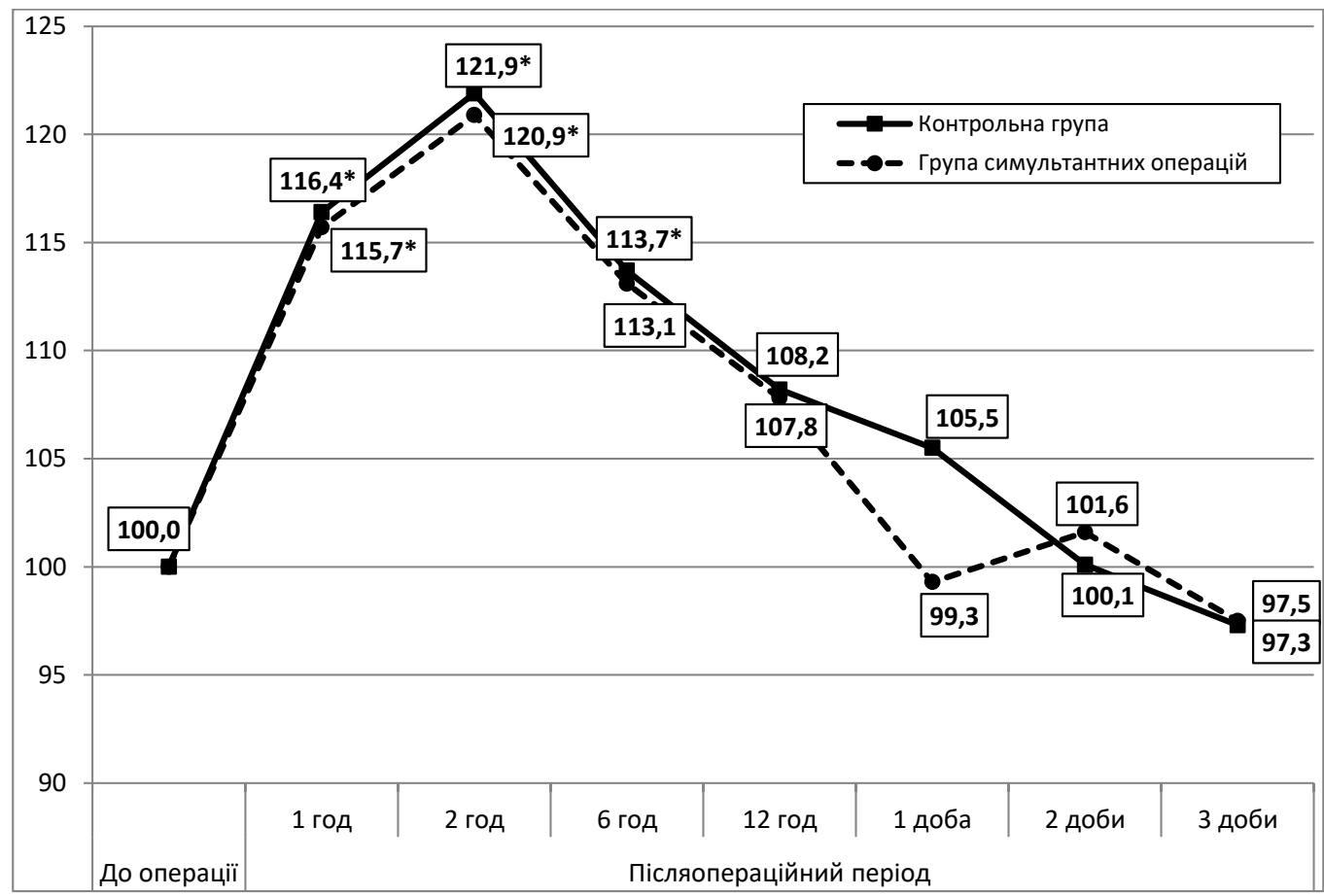

Рис. 4. Динаміка АМо (у відсотках до рівня контролю) пацієнтів контрольної та основної груп у післяопераційному періоді.

Таблиця 5. Величина IH (ум.од.) пацієнтів контрольної та основної груп до операції та в динаміці післяопераційного періоду (Me (LQ;UQ)) - медіана (нижній і верхній квартилі))

\begin{tabular}{||l|c|c|c||}
\hline \hline Період обстеження & Контрольна група & Група симультанних операцій & $\mathrm{p}$ \\
\hline Післяопераційний період & \multicolumn{2}{||}{} \\
\hline 1 год & $211,5(169,5 ; 249,8)$ & $225,4(190,5 ; 210,0)$ & $>0,05$ \\
\hline 2 год & $262,0(208,1 ; 311,8)$ & $298,6(246,5 ; 356,8)$ & $>0,05$ \\
\hline 6 год & $194,9(155,6 ; 229,1)$ & $218,3(184,2 ; 262,2)$ & $>0,05$ \\
\hline 12 год & $170,3(136,1 ; 201,5)$ & $180,1(151,4 ; 217,3)$ & $>0,05$ \\
\hline 1 доба & $155,4(124,1 ; 184,0)$ & $172,8(143,7 ; 203,6)$ & $>0,05$ \\
\hline 2 доби & $173,8(137,6 ; 210,7)$ & $205,1(164,4 ; 245,2)$ & $>0,05$ \\
\hline 3 доби & $117,2(94,1 ; 139,6)$ & $134,0(110,1 ; 166,1)$ & \\
\hline \hline
\end{tabular}

ний результат порівняно з доопераційним рівнем був статистично невірогідним ( $>00,05)$.

Порівняння контрольної та основної груп у динаміці післяопераційного періоду не виявило статистично значущих відмінностей ( $>>0,05)$.

Таким чином, аналіз статистичних показників варіаційної пульсограми в доопераціному періоді не виявив істотних відмінностей між контрольною та основною групами, що свідчить про репрезентативність груп спостереження.
У динаміці післяопераційного періоду до 2 год знижуються величини Мо, $\Delta \mathrm{X}$ та зростають AMo та IH. Це свідчить про зростання активності симпатичної нервової системи та посилення централізації управління серцевим ритмом, що вказує на збільшення стресогенного впливу виконаного операційного втручання. Очевидно, таке збільшення пов'язане зі зниженням впливу лікарських засобів, які застосовували для наркозу. 


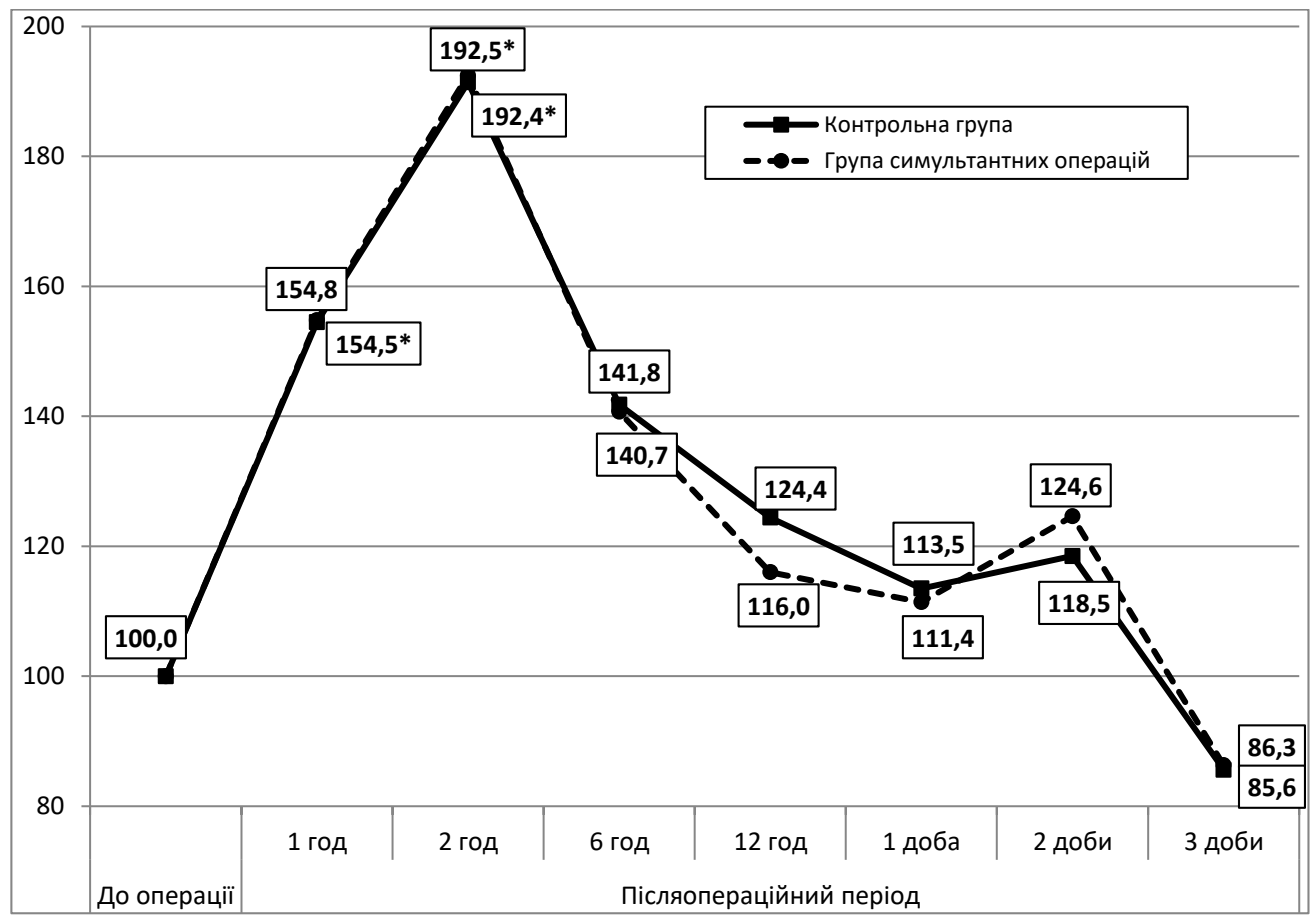

Рис. 5. Динаміка IH (у відсотках до рівня контролю) пацієнтів контрольної та основної груп у післяопераційному періоді.

До 12 год післяопераційного періоду виявлені відхилення досягали доопераційного рівня в обох групах порівняння. Привертає на себе увагу помірне статистично вірогідне зниження величини $\Delta \mathrm{X}$ та тенденція до зростання IH через 2 доби післяопераційного періоду, що є свідченням відтермінованої реакції організму на операційну травму. До 3 доби усі застосовані статистичні показники математичного аналізу серцевого ритму досягали доопераційного рівня.

Однак, незважаючи на види виконаних операційних втручань, і лапароскопічна крурорафія 3 фундоплікацією за Тупе, і симультанні операційні втручання в післяопераційному періоді у всі терміни зумовлювали практично однакові відхилення досліджуваних показників, які статистично вірогідно між групами пацієнтів не відрізнялися. Даний факт свідчить про те, що ступінь стресогенного впливу обох видів операційних втручань за рівнем симпатикотонії та ступенем централізації регуляції серцевого ритму є практично однако-

\section{СПИСОК ЛІТЕРАТУРИ}

1. Адаптаційні можливості після різних видів хірургічних втручань у онкологічних хворих / М. В. Красносельський, Є. М. Крутько, Н. А. Мітряєва [та ін.] // Медицина невідкладних станів. - 2018. - № 8 (95). - С. 94-98.

2. Овечкин А. М. Хирургический стресс-ответ, его патофизиологическая значимость и способы модуляции / вим, незважаючяи на обсяг і тривалість виконаних втручань і свідчить про безпечність і перспективність одномоментних симультатнтних операцій 3 приводу ГСОД та ЖКХ.

Висновок. 1. Моновтручання з приводу грижі стравохідного отвору діафрагми та симультанні втручання за умов розобленої нами техніки лапароскопічних операцій у післяопераційному періоді у всі терміни спостереження супроводжуються практично однаковими відхиленнями статистичних показників варіабельності сецевого ритму.

2. Відсутність у динаміці післяопераційноого періоду статистично значущих відмінностей досліджуваних показників між групами хворих із моно- і симультанними втручаннями за рівнем симпатикотонії та ступенем централізації регуляції серцевого ритму свідчить про однаковий рівень післяопераційного стресу і вказує на безпечність і перспективність одномоментних симультанних операцій.

А. М. Овечкин // Регионарная анастезия и лечение острой боли. - 2008. - Вып. 2. - С. 49-62.

3. Залежність ступеня операційного стресу від виду оперативного втручання з приводу гострого холециститу у пацієнтів за високого операційно-анестезіологічного ризику / М. В. Безручко, С. В. Малик, С. П. Кравченко [та ін.] // Клі- 
нічна хірургія. - 2013. - № 3. - С. 22-25.

4. Оценка вегетативного управления сердцем на основе спектрального анализа вариабельности сердечного ритма / Киселев А. Р., Киричук В. Ф., Гриднев В. И., Колижирина О. М. // Физиология человека. - 2005. - Т. 31, № 6. - С. 37-43.

5. Баевский Р. М. Анализ вариабельности сердечного ритма при использовании различных электрокардиографических систем: метод. рек. / Р. М. Баевский, Г. Г. Иванов, Л. В. Чи- рейкин // Вестник аритмологии. - 2001. - № 24. - С. 1-23. 6. Баевский Р. М. Математический анализ изменений сердечного ритма при стрессе / Р. М. Баевский, О. И. Кириллов, М. С. Клецкин. - М. : Наука, 1984. - 222 с.

7. Баевский Р. М. Оценка и классификация уровней здоровья с точки зрения теории адаптации / Р. М. Баевский // Вестн. АМН СССР. - 1989. - № 8. - С. 73-78.].

\section{REFERENCES}

1. Krasnoselskyy, M.V., Krutko, Ye.M., \& Mitryayeva, N.A. (2018). Adaptatsiini mozhlyvosti pislia riznykh vydiv khirurhichnykh vtruchan u onkolohichnykh khvorykh [Adaptation possibilities after different types of surgical interventions in cancer patients]. Medytsyna nevidkladnykh staniv - Emergency Medicine, 8 (95), 94-98 [in Ukrainian].

2. Ovechkin, A.M. (2008). Khirurgicheskiy stress-otvet, ego patofiziologicheskaya znachimost i sposoby modulyatsii [Surgical stress-response, its pathophisiological significance and modulation ways]. Regionarnaya anasteziya i lechenie ostroy boli - Regional Anesthesia and Acute Pain Treatment, 2, 49-62 [in Russian].

3. Bezruchko, M.V., Malyk, S.V., \& Kravchenko, S.P. (2013) Zalezhnist stupenia operatsiinoho stresu vid vydu operatyvnoho vtruchannia z pryvodu hostroho kholetsystytu u patsiientiv za vysokoho operatsiino-anesteziolohichnoho ryzyku [Dependence of the degree of operative stress on the type of surgical intervention for acute cholecystitis in patients with high surgical and anesthesiological risk]. Klinichna khirurhiia - Clinical Surgery, 3, 22-25 [in Ukrainian].

4. Kiselev, A.R., Kirichuk, V.F., Gridnev, V.I., \& Kolizhiri-

na, O.M. (2005). Otsenka vegetativnogo upravleniya serdtsem na osnove spektralnogo analiza variabelnosti serdechnogo ritma [Assessment of autonomic heart control based on spectral analysis of heart rate variability]. Fiziologiya cheloveka - Human Physiology, 31, 6, 37-43 [in Russian].

5. Bayevskiy, P.M., Ivanov, G.G., \& Chireykin, L.V. (2001). Analiz variabelnosti serdechnogo ritma pri ispolzovanii razlichnykh elektrokardiograficheskikh sistem: metod. rek. [Analysis of heart rate variability using various electrocardiographic systems: Guidelines]. Vestnik aritmologii - Bulletin of Arrhythmology, 24, 1-23 [in Russian].

6. Bayevskiy, R.M., Kirillov, O.I., \& Kletskin, M.S. (1984). Matematicheskiy analiz izmeneniy serdechnogo ritma pri stresse [Mathematical analysis of changes in heart rate during stress]. Moscow: Nauka [in Russian].

7. Bayevskiy, R.M. (1989). Otsenka i klassifikatsiya urovney zdorovya s tochki zreniya teorii adaptatsii [Assessment and classification of levels of health from the point of view of the theory of adaptation]. Vestn. AMN SSSR. - Vestn. Academy of Medical Sciences of the USSR, 8, 73-78 [in Russian].

Отримано 07.09.2020

Електронна адреса для листування: gudyma@tdmu.edu.ua

M. M. HALEY ${ }^{1}$, A. A. HUDYMA², I. YA. DZIUBANOVSKYI², O. I. DZIUBANOVSKYI²

Volyn Regional Hospital ${ }^{1}$

I. Horbachevsky Ternopil National Medical University²

\section{ANALYSIS OF PERIOPERATIVE STRESS IN PATIENTS AFTER SIMULTANEOUS LAPAROSCOPIC SURGERY}

The aim of the work: based on the variability of the heart rhythm to assess the degree of perioperative stress in patients with laparoscopic treatment of hiatal hernia and simultaneous operations.

Material and Methods. A survey of 332 patients with hiatal hernia from 2015 to 2019. All of them underwent laparoscopic crurography with fundoplication according to Tupe. Two groups were formed. Group 1 - the main group included patients who underwent simultaneous laparoscopic surgical treatment of hiatal hernia and gallstone disease -126 people. Group 2 - control group, patients underwent only laparoscopic crurography and fundoplication - 206 patients. To assess the operative stress the day before the surgery and 1, 2, 3, 6 , 12 hours and 1, 2 and 3 days of the postoperative period, a variation pulsegram was registered using the cardiocomplex "CardioLab +" with subsequent determination of the main statistical characteristics according to the method of R. M. Baevsky. Estimation of the probability of differences between the control and main groups was performed using the nonparametric Mann-Whitney test.

Results and Discussion. Mono-interventions for hiatal hernia and simultaneous protrusion under the conditions of our developed technique of laparoscopic operations in the postoperative period in all periods of observation are accompanied by almost identical deviations of statistical indicators of variability of cardiac rhythm. The absence of statistically significant differences in the dynamics of the postoperative period between the groups of patients with mono- and simultaneous interventions on the level of sympathicotonia and the degree of centralization of heart rate regulation indicates the same level of postoperative stress and indicates the safety and viability of simultaneous operations.

Key words: hiatal hernia; lapaproscopic fundoplication; surgical stress. 


\title{
Н. М. ГАЛЕЙ, А. А. ГУДЫМА², И. Я. ДЗЮБАНОВСКИЙ², О. И. ДЗЮБАНОВСКИЙ²
}

Волынская областная больница ${ }^{1}$

Тернопольский национальный медицинский университет имени И. Я. Горбачевского МОз Украины²

\section{АНАЛИЗ ПЕРИОПЕРАЦИОННОГО СТРЕССА У ПАЦИЕНТОВ ПОСЛЕ СИМУЛЬТАННЫХ ЛАПАРОСКОПИЧЕСКИХ ОПЕРАЦИЙ}

\begin{abstract}
Цель работы: на основе вариативности сецевого ритма оценить степень периоперационного стресса у пациентов с лапароскопическим лечением грыжи пищеводного отверстия диафрагмы и симультаннымы операциями.

Материалы и методы. Проведено обследование 332 пациентов, лечившихся по поводу грыж пищеводного отверстия диафрагмы (ГПОД) с 2015 по 2019 г. Всем была выполнена лапароскопическая крурорафия с фундопликацией по Тупэ. Сформировано две группы: в первую - основную группу - включили пациентов, которые проходили симультанное лапароскопическое операционное лечение ГПОД и желчнокаменной болезни (ЖКБ) - 126 человек. Во второй - контрольной группе - пациентам выполняли только лапароскопическую крурорафию и фундопликацию - 206 человек. Для оценки операционного стресса за день до операции и через 1, 2, 3, 6, 12 ч и 1, 2 и 3 суток послеоперационного периода осуществляли регистрацию вариационной пульсограммы с использованием кардиокомплекса “CardioLab +” с последующим определением основных статистических характеристик по методике Р. М. Баевского. Оценку достоверности различий между контрольной и основной группами проводили с использованием непараметрического критерия Манна-Уитни.

Результаты исследований и их обсуждение. Моноинткервенция по поводу грыжи пищеводного отверстия диафрагмы и симультанных операций в условиях разработанной нами техники лапароскопических операций в послеоперационном периоде во все сроки наблюдения сопровождаются практически одинаковыми отклонениями статистических показателей вариабельности сердечного ритма. Отсутствие в динамике послеоперационного периода статистически значимых различий исследуемых показателей между группами больных с моно- и симультанными вмешательствами по уровню симпатикотонии и степенью централизации регуляции сердечного ритма свидетельствует об одинаковом уровне послеоперационного стресса и указывает на безопасность и перспективность симультанных операций.
\end{abstract}

Ключевые слова: грыжа пищеводного отверстия диафрагмы; лапароскопическая фундопликация; операционный стресс. 